\section{REFLEKSI HUKUM}

Jurnal Ilmu Hukum
p-ISSN 2541-4984 | e-ISSN 2541-5417

Volume 5 Nomor 1, Oktober 2020, Halaman 105- 124

DOI: https://doi.org/10.24246/jrh.2020.v5.i1.p105-124

Open access at: http://ejournal.uksw.edu/refleksihukum

Penerbit: Fakultas Hukum Universitas Kristen Satya Wacana

\title{
KEABSAHAN RUISLAG BARANG MILIK DAERAH DENGAN TANAH MILIK YAYASAN
}

\author{
Dyah Hapsari Prananingrum dan Ninon Melatyugra \\ Pusat Studi Reformasi Regulasi untuk Pembangunan (CoRRDev) \\ Fakultas Hukum Universitas Kristen Satya Wacana \\ Korespondensi: dyah.prananingrum@gmail.com
}

Naskah diterima: 25 Maret 2020|Direvisi: 15 September 2020|Disetujui: 30 Oktober 2020

\begin{abstract}
Abstrak
Ruislag merupakan tindakan hukum yang kerap dilakukan Pemerintah Daerah untuk mengoptimalkan pengelolaan Barang Milik Daerah (BMD), salah satunya dengan cara tukarmenukar. Pada praktiknya, ruislag melibatkan subyek hukum Yayasan sebagai pihak yang memiliki aset untuk ditukarkan dengan BMD tersebut, yang mana aset tersebut dapat berupa tanah milik Yayasan. Tulisan ini hendak mempreskripsi hal-hal apa saja yang perlu diperhatikan baik oleh Pemerintah Daerah maupun Yayasan dalam melakukan ruislag. Terdapat dua poin penting yang dikaji dalam tulisan ini yakni terkait organisasi Yayasan sebagai Pemohon ruislag serta kelengkapan dokumen tanah milik Yayasan dimana asal tanah tersebut merupakan hibah. Tulisan ini menggunakan pendekatan konseptual dan peraturan perundang-undangan dalam analisisnya.
\end{abstract}

Kata-kata Kunci: Ruislag; Barang Milik Daerah; Yayasan.

\begin{abstract}
Ruislag is a legal act conducted by the Local Government to optimize its assets, in which one of its forms is exchanging its assets with private assets. In practice, ruislag involves a foundation that owns assets, for instance, land ownership, as a party in ruislag. This article prescribes two main points that shall be noticed by the Local Government and the Foundation regarding the legitimate ruislag conduct. Those two main points highlight the organization of the foundation issue and the administrative aspects of legal documents of the land owned by the foundation, particularly the land that was obtained by a grant. This article uses a conceptual approach and a statutes approach in its analysis.
\end{abstract}

\section{Keywords: Ruislag; Assets of Local Government; Foundation.}




\section{PENDAHULUAN}

Pasal 18 ayat (2) Undang-Undang Dasar Negara Republik Indonesia Tahun 1945 (UUD NRI Tahun 1945) menegaskan bahwa Pemerintahan daerah provinsi, daerah kabupaten, dan kota mengatur dan mengurus sendiri urusan pemerintahan menurut asas otonomi dan tugas pembantuan. Penyelenggaraan urusan pemerintahan tersebut dilaksanakan berdasarkan asas desentralisasi, dekonsentrasi, dan tugas pembantuan. ${ }^{1}$ Dalam rangka mengoptimalkan penyelenggaraan urusan pemerintahan daerah di atas, Pemerintah Daerah berwenang untuk melakukan pengelolaan terhadap Barang Milik Daerah (BMD) yang mana BMD merupakan semua barang yang dibeli atau diperoleh atas beban Anggaran Pendapatan dan Belanja Daerah atau berasal dari perolehan lainnya yang sah. ${ }^{2}$

Pada dasarnya, BMD yang diperlukan untuk penyelenggaraan urusan pemerintahan tidak dapat dipindahtangankan. ${ }^{3}$ Namun bagi BMD yang tidak digunakan untuk penyelenggaraan urusan pemerintahan dapat dilakukan pemindahtanganan dengan cara penjualan; Tukar-menukar; Hibah; atau Penyertaan Modal Pemerintah Pusat/ Daerah. ${ }^{4}$ Tukar-Menukar BMD (atau lebih dikenal dengan istilah ruislag) dilaksanakan dengan pertimbangan: a. untuk memenuhi kebutuhan operasional penyelenggaraan pemerintahan; b. untuk optimalisasi BMD; dan c. tidak tersedia dana dalam APBD. Tukar-Menukar BMD dapat dilakukan dengan pihak: Pemerintah Pusat; Pemerintah Daerah lainnya; Badan Usaha Milik Negara/Daerah atau badan hukum lainnya yang dimiliki negara; atau swasta. ${ }^{5}$ Selain pertimbangan tersebut, tukarmenukar dapat dilakukan karena6:

1. Apabila BMD berupa tanah dan/atau bangunan sudah tidak sesuai dengan tata ruang wilayah atau penataan kota;

2. Guna menyatukan BMD yang lokasinya terpencar;

3. Dalam rangka pelaksanaan rencana strategis pemerintah pusat/ pemerintah daerah;

4. Guna mendapatkan/memberikan akses jalan, apabila obyek Tukar- Menukar adalah BMD berupa tanah dan/atau bangunan; dan atau

5. Telah ketinggalan teknologi sesuai kebutuhan, kondisi, atau ketentuan peraturan perundangundangan, apabila obyek tukarmenukar adalah BMD selain tanah dan/atau bangunan.

Dalam praktiknya, perbuatan tukar-menukar atau ruislag ini melibatkan aset yang berupa tanah yang dimiliki oleh Yayasan. Sebagaimana telah diatur dalam peraturan perundang-undangan, Yayasan merupakan badan hukum yang terdiri atas kekayaan yang dipisahkan dan diperuntukkan untuk mencapai tujuan tertentu di bidang sosial, keagamaan, dan kemanusiaan yang tidak mempu-

Pasal 5 ayat (4) UU No. 23 Tahun 2014 sebagaimana telah diubah terakhir dengan UU No. 9 Tahun 2015.

Pasal 1 angka 2 PP No. 27 Tahun 2014 jo Pasal 1 angka 16 Permendagri No. 19 Tahun 2016.

Pasal 307 UU No. 5 Tahun 2015.

Pasal 54 PP No. 27 Tahun 2014 jo Pasal 329 Permendagri No. 19 Tahun 2016.

Pasal 64 PP No. 27 Tahun 2014 jo Pasal 377 Permendagri No. 19 Tahun 2016.

Pasal 377 ayat (3) Permendagri No. 19 Tahun 2016. 
nyai anggota. ${ }^{7}$ Yayasan sendiri dapat memiliki kekayaan yang berasal dari sejumlah kekayaan yang dipisahkan dalam bentuk uang dan barang dan dapat berasal dari sumbangan atau bantuan yang tidak mengikat, wakaf, hibah, hibah wasiat, dan perolehan lain yang tidak bertentangan dengan anggaran dasar Yayasan dan/atau peraturan perundang-undangan yang berlaku. ${ }^{8}$

Salah satu bentuk kekayaan yang dapat dimiliki oleh Yayasan adalah tanah. Dengan memenuhi ketentuan peraturan perundangundangan, tanah milik Yayasan dapat menjadi objek ruislag yang ditukarkan dengan BMD. Praktik demikian seyogyanya sah manakala dilakukan dengan pra-pemahaman yang komprehensif mengenai keabsahan ruislag yang melibatkan BMD dengan tanah milik Yayasan. Oleh sebab itu, tulisan ini hendak menjabarkan hal-hal apa saja yang harus diperhatikan baik itu oleh Pemerintah dan Yayasan dalam melakukan ruislag agar menghindari potensi sengketa yang muncul di kemudian hari. Tulisan ini merupakan penelitian yang bersifat deskriptif dengan pendekatan konseptual dan peraturan perundang-undangan.

\section{PEMBAHASAN}

Bagian ini terdiri dari tiga bagian utama yakni bagian pertama akan menjelaskan mengenai ruislag yang diatur dalam peraturan perundangundangan, bagian kedua akan menjabarkan karakteristik Yayasan, dan bagian ketiga akan memaparkan aspek keabsahan ruislag BMD dengan tanah milik Yayasan.

\section{Ruislag}

Dalam menjalankan fungsinya, negara (pemerintah) terikat pada asas hukum administrasi negara guna menghindari terjadinya arbitrary power yang dapat menyebabkan kerugian pada warga negara. Dengan demikian, asas hukum administrasi negara menjadi starting point yang bersifat normative statement dalam memberi pedoman kepada negara bagaimana ia harus bertindak dalam memberikan pelayanan terhadap masyarakat.

Salah satu asas hukum administrasi negara yang relevan diterapkan dalam isu ruislag adalah asas legalitas. Asas legalitas menekankan bahwa setiap perbuatan administrasi negara, baik dalam membuat peraturan maupun dalam membuat ketetapan harus berdasarkan hukum yang berlaku. ${ }^{9}$ Berdasarkan perspektif asas legalitas sebagai prinsip umum, maka kesesuaian perilaku negara dengan undang-undang yang sesuai dengan hukum adalah tuntutan profesional bagi negara dalam menjalankan fungsinya.

Kegiatan ruislag merupakan salah satu tindakan pemerintahan yang dapat dilakukan oleh negara berdasarkan hukum nasional sebagai bentuk pengelolaan aset negara. Secara teoretis hal demikian dimungkinkan karena pada prinsipnya Pemerintah Daerah dapat melakukan kontraktualisasi urusan pemerintahan termasuk melakukan ruislag

Pasal 1 UU No. 16 Tahun 2001 jo UU No. 28 Tahun 2004.

Pasal 26 ayat (1) dan (2) UU No. 16 Tahun 2001 jo UU No. 28 Tahun 2004 (Selanjutnya disebut UU No. 16 Tahun 2001).

Sahya Anggara, Ekologi Administrasi: Holistik, Kontemporer dan Kontekstual (Pustaka Setia 2018) 8. 
dengan pihak non pemerintah ${ }^{10}$ dengan memperhatikan perencanaan kebutuhan aset daerah dan perencanaan pemeliharaan aset daerah terlebih dahulu ${ }^{11}$.

Koloay menjelaskan dampak positif dari ruislag ini adalah pemanfaatan aset yang lebih tepat guna, berhasil guna, penyediaan prasarana dan sarana yang tidak mengganggu anggaran negara, serta mendukung rencana umum tata ruang sesuai dengan target yang telah ditetapkan. ${ }^{12}$

Vis a vis, kegiatan ruislag harus pula tunduk terhadap asas legalitas dimana negara wajib untuk melihat hukum positif yang mengatur kegiatan tukar-menukar secara komprehensif. Secara substantif, terdapat dua hal yang harus diperhatikan adalah pertama, mengenai wewenang pejabat publik yang terlibat dalam kegiatan ruislag dan kedua, konsep ruislag sebagai bentuk pengelolaan BMD. Sedangkan secara formal, pelaksanaan ruislag harus sesuai dengan tata cara mengenai perjanjian ruislag.

Terkait dengan wewenang pejabat publik, PP No. 27 Tahun 2014 mengatur tiga pihak dalam proses ruislag yakni Walikota, Sekretaris Daerah, dan Kepala Satuan Kerja Perangkat Daerah. Berdasarkan Pasal 5 ayat (1) dan ayat (2) PP No. 27 Tahun 2014, Walikota merupakan pemegang kekuasaan pengelolaan BMD yang memiliki wewenang dan tanggung jawab dalam menetapkan kebijakan pengelolaan BMD; menetapkan Penggunaan, Pemanfaatan, atau Pemin- dah-tanganan BMD berupa tanah dan/atau bangunan; menetapkan kebijakan pengamanan dan pemeliharaan BMD; menetapkan pejabat yang mengurus dan menyimpan BMD; mengajukan usul Pemindahtanganan BMD yang memerlukan persetujuan DPRD; menyetujui usul Pemindahtanganan, Pemusnahan, dan Penghapusan BMD sesuai batas kewenangannya; menyetujui usul Pemanfaatan BMD berupa sebagian tanah dan/atau bangunan dan selain tanah dan/atau bangunan; dan menyetujui usul Pemanfaatan BMD dalam bentuk kerja sama penyediaan infrastruktur.

Sedangkan Sekretaris Daerah yang merupakan Pengelola BMD memiliki wewenang dan tanggung jawab sesuai Pasal 5 ayat (3) dan ayat (4) PP No. 27 Tahun 2014 yakni meneliti dan menyetujui rencana kebutuhan BMD; meneliti dan menyetujui rencana kebutuhan pemeliharaan/perawatan BMD; mengajukan usul Pemanfaatan dan Pemindahtanganan BMD yang memerlukan persetujuan Walikota; mengatur pelaksanaan Penggunaan, Pemanfaatan, Pemusnahan, dan Penghapusan BMD; mengatur pelaksanaan Pemindahtanganan BMD yang telah disetujui oleh Walikota atau DPRD; melakukan koordinasi dalam pelaksanaan Inventarisasi BMD; dan melakukan pengawasan dan pengendalian atas pengelolaan BMD.

Sementara itu Kepala Satuan Kerja Perangkat Daerah, berdasarkan Pasal 8 ayat (1) dan ayat (2) PP No. 27

\footnotetext{
10 Umbu Rauta, Titon Slamet Kurnia, dan Arie Siswanto, Telaah Teoretis dan Yuridis Tukar Menukar Barang Milik Daerah dengan Swasta' (2017) 24 (2) Jurnal Hukum Ius Quia Iustum 252, 232-254.

11 Era Nandya Febriana, Jayus, Rosita Indrayati, 'Pengelolaan Barang Milik Daerah berdasarkan Peraturan Pemerintah Nomor 27 Tahun 2014 tentang Pengelolaan Barang Milik Negara/Daerah' (2017) 4 (2) Jurnal Lentera Hukum 138, 135-156.

12 Renny N.S. Koloay, 'Dampak Positif dan Negatif dalam Tukar Guling Barang Milik Daerah' (2016) 3 (8) Jurnal Ilmu Hukum 39, 47.
} 
Tahun 2014, yang merupakan Pengguna BMD memiliki wewenang dan tanggung jawab untuk mengajukan rencana kebutuhan dan penganggaran BMD bagi satuan kerja perangkat daerah yang dipimpinnya; mengajukan permohonan penetapan status Penggunaan BMD yang diperoleh dari beban APBD dan perolehan lainnya yang sah; melakukan pencatatan dan Inventarisasi BMD yang berada dalam penguasaannya; menggunakan BMD yang berada dalam penguasaannya untuk kepentingan penyelenggaraan tugas dan fungsi satuan kerja perangkat daerah yang dipimpinnya; mengamankan dan memelihara BMD yang berada dalam penguasaannya; mengajukan usul Pemanfaatan dan Pemindahtanganan BMD berupa tanah dan/ atau bangunan yang tidak memerlukan persetujuan DPRD dan BMD selain tanah dan/atau bangunan; menyerahkan BMD berupa tanah dan / atau bangunan yang tidak digunakan untuk kepentingan penyelenggaraan tugas dan fungsi satuan kerja perangkat daerah yang dipimpinnya dan sedang tidak dimanfaatkan Pihak Lain, Walikota melalui Pengelola Barang; mengajukan usul Pemusnahan dan Penghapusan BMD; melakukan pembinaan, pengawasan, dan pengendalian atas Penggunaan BMD yang berada dalam penguasaannya; dan menyusun dan menyampaikan laporan barang pengguna semesteran dan laporan barang pengguna tahunan yang berada dalam penguasaannya kepada Pengelola Barang.

Terkait dengan ruislag sebagai bentuk pengelolaan BMD, Pasal 1 angka 2 PP No. 27 Tahun 2014 mendefinisikan BMD sebagai barang yang dibeli atau diperoleh atas beban Anggaran Pendapatan dan Belanja
Daerah atau berasal dari perolehan lainnya yang sah. Untuk dapat memaksimalkan potensi BMD, maka pengelolaan terhadap BMD dilakukan berdasarkan asas fungsionalitas, kepastian hukum, transparansi, efisiensi, akuntabilitas, dan kepastian nilai. Berdasarkan Pasal 3 PP No. 27 Tahun 2014, pengelolaan BMD dimungkinkan dalam bentuk pemindahtanganan atau pengalihan kepemilikan BMD dengan ketentuan bahwa BMD yang ingin dipindahtangankan bukan merupakan BMD yang diperlukan untuk penyelenggaraan urusan pemerintahan. Hal tersebut sesuai pula dengan Pasal 307 ayat (1) UU No. 23 Tahun 2014 dan Pasal 54 ayat (2) PP No. 27 Tahun 2014, serta Pasal 329 Permendagri No. 19 Tahun 2016. Pemindahtanganan BMD dapat dilakukan dengan cara berikut:
a. Penjualan;
b. Tukar-menukar;
c. Hibah; dan
d. Penyertaan modal Pemerintah Pusat/Daerah.
Lebih spesifik, Pasal 1 angka 19 PP No. 27 Tahun 2014 mendefinisikan Tukar-menukar adalah pengalihan kepemilikan Barang Milik Negara/ Daerah yang dilakukan antara Pemerintah Pusat dengan Pemerintah Daerah, antar Pemerintah Daerah, atau antara Pemerintah Pusat/Pemerintah Daerah dengan pihak lain, dengan menerima penggantian utama dalam bentuk barang, paling sedikit dengan nilai seimbang.

Pelaksanaan tukar-menukar dilakukan dengan pertimbangan sebagaimana dalam Pasal 64 ayat (1) PP No. 27 Tahun 2014, sebagai berikut:

a. untuk memenuhi kebutuhan operasional penyelenggaraan pemerintahan; 
b. untuk optimalisasi Barang Milik Negara/Daerah; dan

c. tidak tersedia dana dalam Anggaran Pendapatan dan Belanja Negara/Daerah.

Adapun yang menjadi pertimbangan lain dalam melakukan tukarmenukar diatur dalam Pasal 377 ayat

(3) Permendagri No. 19 Tahun 2016:

a. apabila BMD berupa tanah dan/atau bangunan sudah tidak sesuai dengan tata ruang wilayah atau penataan kota;

b. guna menyatukan BMD yang lokasinya terpencar;

c. dalam rangka pelaksanaan rencana strategis pemerintah pusat/pemerintah daerah;

d. guna mendapatkan/memberikan akses jalan, apabila objek tukarmenukar adalah BMD berupa tanah dan/atau bangunan; dan/ atau

e. telah ketinggalan teknologi sesuai kebutuhan, kondisi, atau ketentuan peraturan perundangundangan, apabila objek tukarmenukar adalah BMD selain tanah dan/atau bangunan.

Ruislag BMD dapat dilakukan dengan pihak pemerintah pusat, pemerintah daerah lainnya, BUMN/ BUMD atau badan hukum lainnya yang dimiliki negara, pemerintah desa, maupun swasta (baik berbentuk badan hukum maupun perseorangan).

Menurut Pasal 65 ayat (1) PP No.

27 Tahun 2014 dan Pasal 378 Permendagri No. 19 Tahun 2016, terdapat tiga jenis objek tukarmenukar BMD yakni tanah dan/atau bangunan yang telah diserahkan kepada Walikota, tanah dan/atau bangunan yang berada pada pengguna barang, atau selain tanah/bangunan. Untuk tanah dan/atau bangunan yang berada pada pengguna barang, dapat merupakan tanah dan/atau bangunan yang masih dipergunakan untuk penyelenggaraan tugas dan fungsi pengguna barang, tetapi tidak sesuai dengan tata ruang wilayah atau penataan kota.

Lebih lanjut dalam melakukan ruislag, Pasal 379 Permendagri No. 19 Tahun 2016 mengatur terdapat tiga kajian yang harus dianalisis sebelumnya yakni:

a. Aspek teknis, yang antara lain adalah kebutuhan pengelola barang atau pengguna barang serta spesifikasi barang yang dibutuhkan.

b. Aspek ekonomis, meliputi kajian terhadap nilai BMD yang dilepas dan nilai barang pengganti.

c. Aspek yuridis, yang antara lain tata ruang wilayah dan penataan kota serta bukti kepemilikan.

Bentuk barang pengganti ruislag itu sendiri dapat berupa barang sejenis maupun tidak sejenis. Tanah dan/atau bangunan merupakan barang pengganti utama tukar-menukar BMD yang berupa tanah. Dijelaskan lebih lanjut, bahwa barang pengganti tersebut harus berada dalam kondisi siap digunakan pada tanggal penandatanganan perjanjian ruislag atau Berita Acara Serah Terima (BAST).

Terkait dengan nilai barang pengganti, Pasal 382 Permendagri No. 19 Tahun 2016 mengatur bahwa nilai barang pengganti atas ruislag paling sedikit seimbang dengan nilai wajar BMD yang dilepas. Apabila nilai barang pengganti lebih kecil daripada nilai wajar BMD yang dilepas, mitra tukar-menukar wajib menyetorkan ke rekening Kas Umum Daerah atas sejumlah selisih nilai antara nilai wajar barang milik daerah yang dilepas dengan nilai barang pengganti. Penyetoran selisih nilai tersebut 
dilaksanakan paling lambat 2 hari kerja sebelum Berita Acara Serah Terima (BAST) ditandatangani. Selisih nilai dituangkan dalam perjanjian ruislag. persetujuan Walikota berdasarkan pertimbangan dari SKPD terkait. Konsultan pengawas tersebut merupakan membangun bangunan barang mengharuskan mitra ruislag.

Lebih lanjut Pasal 383 Permendagri No. 19 Tahun 2016 mengatur apabila pelaksanaan ruislag pengganti, mitra ruislag menunjuk konsultan pengawas dengan badan hukum yang bergerak di bidang pengawasan konstruksi. Adapun biaya konsultan pengawas menjadi tanggung jawab mitra ruislag.

Adapun tata cara ruislag dapat disimpulkan dalam bagan di bawah ini.

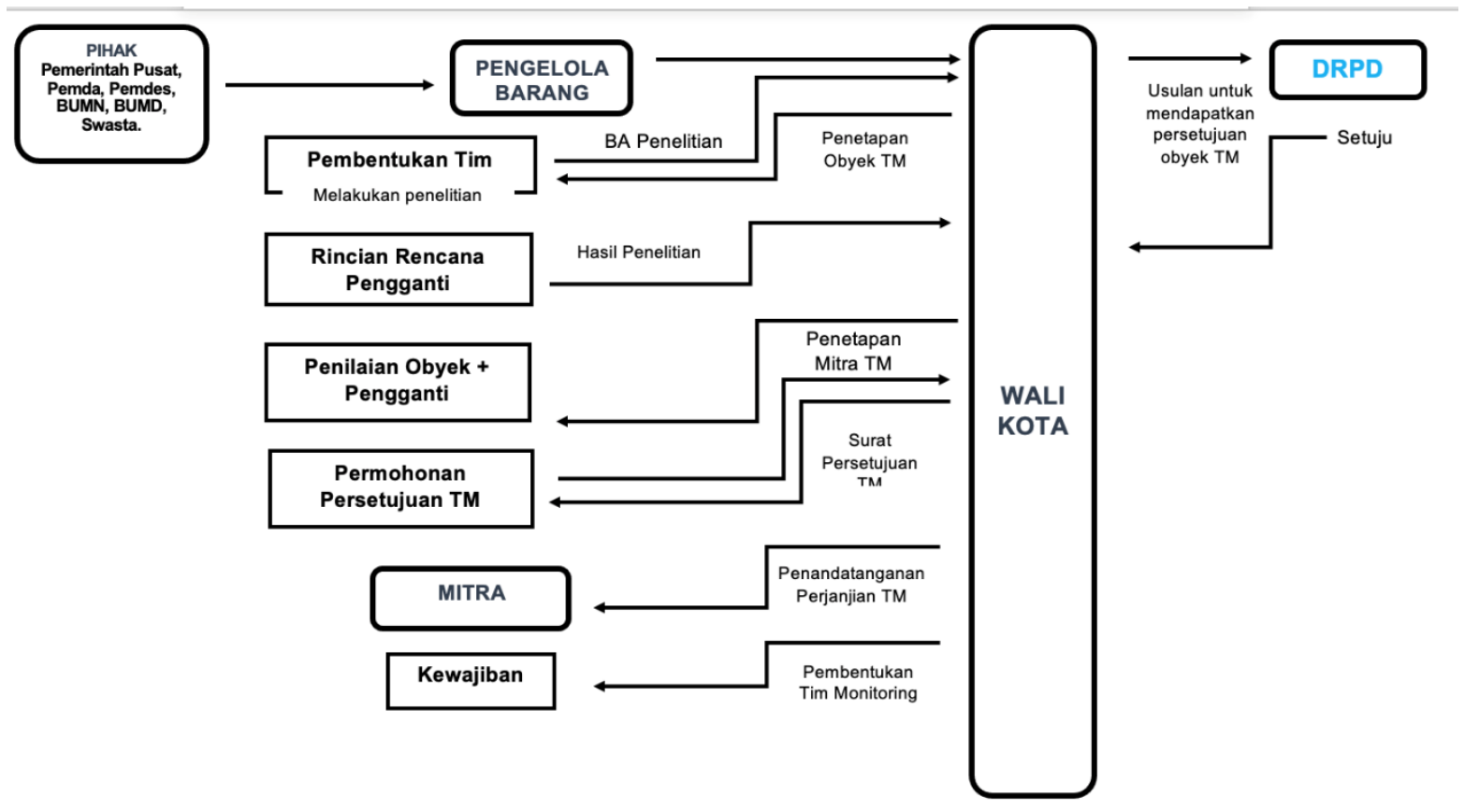




\section{Yayasan}

Sebagaimana telah disinggung di bagian sebelumnya, Yayasan merupakan badan hukum yang terdiri atas kekayaan yang dipisahkan ${ }^{13}$ dan diperuntukkan untuk mencapai tujuan tertentu di bidang sosial, keagamaan, dan kemanusiaan yang tidak mempunyai anggota. ${ }^{14}$ Sebagai subyek hukum ${ }^{15}$ berbentuk badan hukum yang merupakan suatu personifikasi atau bestendigheid ${ }^{16}$, Yayasan membutuhkan organ untuk menjalankan Yayasan dengan kewenangan hukum ${ }^{17}$ yang ia miliki. Organ Yayasan terdiri dari Pembina, Pengurus dan Pengawas.

1) Pembina

Pembina merupakan organ tertinggi dalam Yayasan apabila dibandingkan dengan organ yang lain. Karena organ ini dibentuk sebagai pengganti pendiri yang telah memisahkan harta kekayaannya guna mencapai tujuan Yayasan yang pada faktanya, pendiri Yayasan ini di kemudian hari sangat mungkin tidak ada lagi. Pendiri memiliki maksud dan tujuan tertentu dalam mendirikan Yayasan. Meninggalnya seorang pendiri dapat mengakibatkan kegiatan Yayasan berlangsung tidak sejalan dengan pendirian Yayasan. Di sinilah peran penting dari Pembina sebagai kepanjangan tangan dari pendiri un- tuk menjaga Yayasan tetap dalam arah dan tujuan yang telah ditetapkan oleh pendiri Yayasan. Oleh karena itu, seorang Pembina haruslah seseorang yang dinilai mempunyai dedikasi tinggi untuk mencapai maksud dan tujuan Yayasan sesuai dengan Pasal 28 ayat (3) UU No. 16 Tahun 2001 Jo. UU No. 28 Tahun 2004.

Menjadi anggota Pembina tidak dilakukan dengan cara pemilihan, namun pengangkatan. Pengangkatan anggota pembina dilakukan berdasarkan rapat anggota pembina. Adapun yang dapat diangkat menjadi Pembina adalah pendiri Yayasan ataupun mereka yang diputuskan oleh rapat anggota Pembina. Anggota Pembina tidak boleh merangkap sebagai anggota Pengurus dan atau anggota Pengawas karena dikhawatirkan akan menimbulkan konflik kepentingan dalam menjalankan tugas dan kewenangannya. Apabila karena suatu sebab Yayasan tidak lagi memiliki Pembina, maka dalam jangka waktu tiga puluh hari sejak kekosongan organ Yayasan tersebut diangkatlah Pembina melalui rapat gabungan yang dilakukan oleh anggota Pengurus dan anggota Pengawas.

Kriteria bagi seorang anggota Pembina yang dimunculkan dalam Pasal 28 ayat (3) UU No. 16 Tahun 2001 jo. UU No. 28 Tahun 2004 di atas bersifat subjektif walaupun dapat

\footnotetext{
13 Dyah Hapsari Prananingrum, 'Telaah terhadap Esensi Subyek Hukum: Manusia dan Badan Hukum' (2014) 8 (1) Jurnal Refleksi Hukum 11.

14 Pasal 1 UU No. 16 Tahun 2001 jo UU No. 28 Tahun 2004.

15 Subyek hukum adalah segala sesuatu yang dapat memperoleh hak dan kewajiban dari hukum. Sudikno, Mengenal Hukum (Suatu Pengantar) (Liberty 1988) 53. Hal tersebut ditegaskan oleh Subekti dalam Subekti, Pokok-Pokok Hukum Perdata (Pembimbing Masa 1996) 19. Lihat juga Titik Triwulan Tutik, Hukum Perdata dalam Sistem Hukum Indonesia (Prenada Media Group 2008) 40.

16 Man. S. Sastrawidjaja, Bunga Rampai Hukum Dagang (PT. Alumni 2005) 128-129. Lihat juga Arief Sidharta, Bernard, Refleksi tentang Struktur Imu Hukum (Mandar 2000) 35.

17 Kewenangan hukum merupakan kecakapan untuk menjadi pendukung subyek hukum yang diberikan oleh hukum obyektif. L.J. van Apeldoorn, Pengantar Ilmu Hukum (Pradnya Paramita 1983) 203.
} 
didasarkan pada bukti-bukti yang bersifat objektif. Mempunyai dedikasi yang tinggi merupakan satu kriteria yang bersifat subjektif, karena menilai seseorang memiliki dedikasi atau tidak ataupun menilai apakah dedikasi yang dimiliki orang tersebut tinggi, sedang atau rendah merupakan kriteria yang sulit untuk diukur. Disayangkan tidak ditemukan penjelasan dari pengaturan Pasal 28 ayat (3) UU No. 16 Tahun 2001 jo. UU No. 28 Tahun 2004, sehingga tidak diperoleh penjelasan pengaturan pengangkatan Pembina.

Pembina adalah organ Yayasan yang mempunyai kewenangan yang tidak diserahkan kepada Pengurus atau Pengawas oleh UU No. 16 Tahun 2001 jo. UU No. 28 Tahun 2004 maupun Anggaran Dasar. Pasal 28 ayat (2) UU No. 16 Tahun 2001 jo. UU No. 28 Tahun 2004 menyebutkan, bahwa kewenangan yang dimiliki oleh pembina yang tidak dapat diserahkan kepada pengurus dan pengawas meliputi:

a) Keputusan mengenai perubahan anggaran dasar.

b) Pengangkatan dan pemberhentian anggota Pengurus dan anggota Pengawas.

c) Penetapan kebijakan umum Yayasan berdasarkan Anggaran Dasar Yayasan.

d) Pengesahan program kerja dan rancangan anggaran tahunan Yayasan.

e) Penetapan keputusan mengenai penggabungan atau pembubaran Yayasan.

Berdasarkan ketentuan di atas, kewenangan untuk memutuskan perubahan Anggaran Dasar, pengangkatan dan pemberhentian Pengurus dan Pengawas, penetapan kebijakan umum Yayasan dan keputusan peng- gabungan atau pembubaran Yayasan, serta pengesahan program kerja dan rancangan anggaran tahunan Yayasan, harus dilakukan oleh Pembina dan tidak dapat diserahkan pada Pengurus ataupun Pengawas.

2) Pengawas

Pengawas adalah organ Yayasan yang bertugas melakukan pengawasan serta memberi nasihat kepada Pengurus dalam menjalankan kegiatan Yayasan. Seperti halnya badan hukum koperasi, terdapat organ Pengawas yang bertugas mengawasi kinerja Pengurus koperasi. Demikian pula pada badan hukum Yayasan, Pengurus memiliki kewenangan yang luas yang diawasi oleh Pengawas Yayasan.

Pengawas Yayasan diangkat dan sewaktu-waktu dapat diberhentikan berdasarkan keputusan rapat Pembina. Pengawas Yayasan diangkat oleh Pembina berdasarkan keputusan rapat Pembina untuk jangka waktu selama lima tahun dan dapat diangkat kembali untuk satu kali masa jabatan. Yayasan memiliki pengawas minimal satu orang dan tidak boleh merangkap sebagai Pembina ataupun Pengurus. Larangan rangkap jabatan ini dituangkan secara tegas di dalam Pasal 40 ayat (4) UU No. 16 Tahun 2001 jo. UU No. 28 Tahun 2004. Rangkap jabatan antara Pengawas dengan Pengurus ataupun Pembina berimplikasi pada tidak dapat dilaksanakan tugas pengawasan karena terjadi konflik kepentingan.

Selanjutnya, orang perseorangan yang diangkat sebagai Pengawas haruslah orang perseorangan yang mampu melakukan perbuatan hukum. Dengan demikian, tugas pengawasan yang diembannya dapat dipertanggungjawabkan, terlebih Pengawas berdasarkan Pasal 43 ayat (1) UU No. 16 Tahun 2001 jo. UU No. 28 Tahun 
2004 yang mengatur bahwa Pengawas dapat memberhentikan sementara anggota Pengurus dengan menyebutkan alasannya. Penghentian sementara Pengurus ini menjadi wewenang dari Pengawas. Pengawas dapat memberhentikan sementara anggota Pengurus untuk kemudian ditindaklanjuti oleh Pembina. Pembina wajib memanggil dan memberikan waktu untuk membela diri dan memberi keputusan untuk mencabut atau memberhentikan anggota Pengurus. Namun bila Pembina tidak melaksanakan, maka pemberhentian itu gugur demi hukum.

Mengenai wewenang, tugas dan tanggung jawab Pengawas ini diatur dalam Anggaran Dasar Yayasan, sesuai dengan Pasal 40 ayat (2) UU No. 16 Tahun 2001 jo. UU No. 28 Tahun 2004, bahwa Yayasan memiliki pengawas sekurang-kurangnya satu orang Pengawas yang memiliki wewenang, tugas dan tanggung jawab yang diatur dalam Anggaran Dasar. Namun demikian, pada dasarnya pengawas dalam menjalankan tugasnya harus didasarkan pada itikad baik dan penuh tanggung jawab guna kepentingan Yayasan. ${ }^{18}$

Bila sebaliknya Pengawas tidak menjalankan tugas dan wewenangnya dengan sebaik-baiknya, bahkan menimbulkan kepailitan bagi Yayasan, maka Pengawas harus bertanggung jawab. Pasal 47 UU No. 16 Tahun 2001 jo. UU No. 28 Tahun 2004 mengatur tentang tanggung jawab pengawas dalam hal terjadinya kepailitan Yayasan. Dalam hal kepailitan terjadi karena kesalahan atau kelalaian Pengawas dalam melakukan tugas pengawasan dan kekayaan Yayasan tidak cukup untuk menutup kerugian akibat kepailitan tersebut, setiap anggota Pengawas secara tanggung renteng bertanggung jawab atas kerugian tersebut. Anggota Pengawas Yayasan yang dapat membuktikan bahwa kepailitan bukan karena kesalahan atau kelalaian tidak bertanggung jawab secara tanggung renteng atas kerugian tersebut.

Setiap anggota Pengawas yang dinyatakan bersalah dalam melakukan pengawasan Yayasan yang menyebabkan kerugian bagi Yayasan, masyarakat, dan atau Negara berdasarkan putusan pengadilan dalam jangka waktu paling lama lima tahun sejak putusan tersebut memperoleh kekuatan hukum tetap tidak dapat diangkat menjadi Pengawas Yayasan manapun.

3) Pengurus

Pengurus adalah organ Yayasan yang melaksanakan kepengurusan Yayasan. Pengurus Yayasan diangkat oleh Pembina berdasarkan keputusan rapat Pembina untuk jangka waktu lima tahun dan dapat diangkat kembali untuk satu kali masa jabatan.

Pengurus Yayasan bertanggung jawab penuh atas kepengurusan Yayasan untuk kepentingan dan tujuan Yayasan. Selain itu, Pengurus juga berhak mewakili Yayasan baik di dalam maupun di luar pengadilan. Pengurus dapat mengangkat dan memberhentikan pelaksana kegiatan Yayasan yang melaksanakan kegiatan Yayasan sehari-hari. Pasal 31 ayat (1) UU No. 16 Tahun 2001 jo. UU No. 28 Tahun 2004 menyatakan bahwa Pengurus adalah organ Yayasan yang melaksanakan kepengurusan Yayasan. Pasal 35 ayat (1) mengatur bahwa Pengurus Yayasan bertanggung jawab penuh atas kepengurusan Yayasan

18 Pasal 42 UU No. 16 Tahun 2001 jo. UU No. 28 Tahun 2004. 
untuk kepentingan dan tujuan Yayasan serta berhak mewakili Yayasan baik di dalam maupun diluar Pengadilan.

Dengan demikian, pengurus adalah organ yang mewakili kepentingan Yayasan selaku subjek hukum mandiri. Yayasan adalah sebab keberadaan (raison d'etre) pengurus, karena apabila tidak ada Yayasan juga tidak ada pengurus. Itu sebabnya mengapa Pengurus sudah sepatutnya mengabdi kepada kepentingan Yayasan. Pengurus bukan wakil pemegang saham tetapi Pengurus adalah wakil Yayasan selaku persona standi in judicio atau subjek hukum mandiri.

Pada penjelasan Pasal 37 ayat (2) mengatur jika Pengurus melakukan perbuatan hukum untuk dan atas nama Yayasan, Anggaran Dasar dapat membatasi kewenangan tersebut dengan menentukan bahwa untuk perbuatan hukum tertentu diperlukan persetujuan terlebih dahulu dari Pembina dan atau Pengawas, misalnya untuk menjaminkan kekayaan Yayasan.

Menurut Pasal 31 ayat (1) dan Pasal 35 ayat (1), maka dapat disimpulkan adanya dua tugas dari Pengurus yang terkait satu dengan yang lain, yaitu:

a) Tugas manajemen

Tugas Pengurus mengenai manajemen, dalam arti Pengurus merupakan organ Yayasan yang memimpin Yayasan. Tugas manajemen yang diemban Pengurus ini sesuai dengan Pasal 31 ayat (1) UU No. 16 Tahun 2001 jo. UU No. 28 Tahun 2004, bahwa Penguruslah yang merupakan organ Yayasan yang menjalankan pengurusan Yayasan.

b) Tugas representasi

Tugas representasi dari Pengurus adalah mewakili Yayasan di dalam maupun di luar pengadilan. Pengurus mewakili Yayasan dalam hal Yayasan sebagai badan hukum menghadapi masalah hukum dan diselesaikan melalui pengadilan. Mewakili Yayasan di luar pengadilan pada prinsipnya berkaitan dengan tindakan Pengurus dalam membuat kontrakkontrak dengan pihak ketiga dimana kontrak-kontrak tersebut akan memiliki akibat hukum yang mengikat Yayasan sebagai badan hukum.

Pasal 35 UU No. 16 Tahun 2001 jo. UU No. 28 Tahun 2004 mengatur tugas representasi Pengurus secara lebih lanjut sebagai berikut.

a) Pengurus Yayasan bertanggung jawab penuh atas kepengurusan Yayasan untuk kepentingan dan tujuan Yayasan serta berhak mewakili Yayasan, baik di dalam maupun di luar pengadilan.

b) Setiap pengurus menjalankan tugas dengan itikad baik dan penuh tanggung jawab untuk kepentingan dan tujuan Yayasan

c) Dalam menjalankan tugas sebagaimana dimaksud dalam ayat (2), Pengurus dapat mengangkat dan memberhentikan pelaksana kegiatan Yayasan.

d) Ketentuan mengenai syarat dan tata cara pengangkatan dan pemberhentian pelaksana kegiatan Yayasan diatur dalam Anggaran Dasar Yayasan.

Berdasarkan pengaturan dalam Pasal 35, Pengurus bertanggung jawab penuh atas kepengurusan dalam Yayasan. Pengurus merupakan organ yang mewakili Yayasan baik di dalam maupun di luar pengadilan, sesuai dengan asas persona standi in judicio. Begitu pentingnya Pengurus dalam 
suatu Yayasan, maka faktor kesuksesan suatu Yayasan dimulai dari adanya komitmen dari para pendiri dan Pengurus Yayasan.19 Sebagai suatu lembaga nirlaba, Yayasan hanya mengandalkan kepemimpinan sukarela (volunteer leadership) Pengurus yang mau dan mampu menanggalkan kepentingan pribadinya untuk kepentingan Yayasan, walaupun dimungkinkan pengurus Yayasan dengan syarat tertentu dapat menerima gaji. Namun demikian, yang dituntutkan pada pengurus ini adalah profisionalisme untuk menjalankan Yayasan agar mencapai tujuannya di bawah pengawasan organ lain dalam Yayasan, yaitu Pengawas serta Pembina. Pengurus sebagai organ yang menjaga Yayasan tetap pada tujuannya serta agar aktivitas Yayasan tidak menyimpang dari apa yang telah digariskan pendiri Yayasan. Selanjutnya, Pengurus dilarang mengadakan perjanjian dengan organisasi yang terafiliasi dengan Yayasan, Pembina, Pengurus, dan atau Pengawas Yayasan, atau seseorang yang bekerja pada Yayasan, kecuali dalam hal perjanjian tersebut bermanfaat bagi tercapainya maksud dan tujuan Yayasan.

Berdasarkan pengaturan mengenai tanggung jawab dan kewenangan Pengurus, maka dapat dikonstruksikan mengenai hubungan hukum antara Pengurus dengan Yayasan seperti halnya hubungan antara Direksi dengan PT. Hubungan antara Direksi dengan PT, menurut beberapa ahli hukum bisnis seperti Purwosutjipto (1980) dan Sukardono (1983) berpendapat bahwa sifatnya adalah kombinasi antara hubungan perburuhan dan hubungan pemberian kuasa. Namun, pendapat yang menyatakan bahwa hubungan Direksi dengan PT didasarkan pada hubungan perburuhan yang sub-ordinasi menurut Nindyo Pramono tidaklah tepat, karena UUPT mengatur bahwa yang mewakili PT untuk melakukan tindakan hukum adalah Direksi. Pernyataan bahwa Pengurus yang mewakili PT dalam melakukan hubungan perburuhan juga merupakan buruh adalah tidak sejalan dengan pengaturan good corporate governance. Lebih tepat bila dinyatakan bahwa sifat hubungan hukum antara Direksi dengan PT yang diwakili adalah hubungan hukum perwakilan (volmacht) dengan secara spesifik mengambil jenis perwakilan yang dikenal dalam surseance van betaling yang disebut bewindvoering. Pengurus PT mewakili PT dalam mengurus dan memelihara (beheer en beschikking daden). ${ }^{20}$ Demikian pula konstruksi hubungan hukum yang terjadi antara Direksi dengan PT dapat digunakan untuk menggambarkan hubungan antara Pengurus dengan Yayasan. Hubungan antara Pengurus dengan Yayasan adalah hubungan perwakilan (volmacht). Keterhubungan antara pengurus dengan Yayasan dapat dianalogkan dengan hubungan antara principal dan agen.

Sebagaimana telah dijelaskan di awal, bahwa Yayasan dapat memiliki aset. Financial Accounting Standards Board (FASB) mendefinisikan aset sebagai (SFAC No 6, prg 25): Assets are probable future economic benefits

19 Panggabean H.P., Praktek Peradilan Menangani Kasus Aset Yayasan dan Upaya Penanganan Sengketa melalui Alternatif Penyelesaian Sengketa (Pustaka Sinar Harapan 2002) 159.

20 Nindyo Pramono., 'Tanggung Jawab dan Kewajiban Pengurus PT (Bank) Menurut UU No. 40 Tahun 2007 tentang Perseroan Terbatas' (2007) 5 (3) Buletin Hukum Perbankan dan Kebanksentralan 16. 
obtained or controlled by a particular entity as a result of past transactions or events $^{21}$ (aset adalah manfaat ekonomik masa datang yang cukup pasti atau diperoleh atau dikuasai/ dikendalikan oleh suatu entitas akibat transaksi atau kejadian masa lalu). Dengan makna yang hampir sama, IASC (Internasional Accounting Standards Committee) mendefinisikan aset sebagai an assets is resource controlled by the enterprise as a result of past events and from which future economic benefits are expected to flow to the enterprise. ${ }^{22}$ Pengertian aset menurut Statement of Accounting Concepts No. 4, Australian Accounting Standard Board (AASB) adalah ... service potential or future economic benefits controlled by the reporting entity as a result of past transaction or other past events. ${ }^{23}$ Berdasarkan definisi FASB dan AASB tersebut, aset mempunyai sifat memberikan manfaat ekonomik (economic benefits) dan bukan sebagai sumber ekonomik (resources) karena manfaat ekonomik tidak membatasi bentuk atau jenis sumber ekonomik yang dapat dimasukkan sebagai aset. Sedangkan menurut IASC, aset bersifat sebagai sumber ekonomi sebagai hasil peristiwa di masa lalu dan mendatangkan keuntungan dimasa depan.

Sementara itu, pengertian aset secara umum menurut Siregar ${ }^{24}$ adalah barang (thing) atau sesuatu barang (anything) yang mempunyai nilai ekonomi (economic value), nilai komersial (commercial value) atau nilai tukar (exchange value) yang dimiliki oleh badan usaha, instansi atau individu (perorangan). Dalam perspektif ilmu ekonomi, aset didefinisikan secara komprehensif, diantaranya oleh Sprague ${ }^{25}$ yang menyatakan aset yang dimiliki perusahaan harus memiliki nilai dan perusahaan harus dapat menikmati/memanfaatkan nilai tersebut. Paton ${ }^{26}$ mendefinisikan aset sebagai kekayaan baik dalam bentuk fisik atau bentuk lainnya yang memiliki nilai bagi suatu entitas. Sementara itu, Vatter ${ }^{27}$ lebih merinci lagi dengan meninjau aset dari sisi manfaat yang dihasilkan dengan mendefinisikan aktiva sebagai manfaat ekonomi masa yang akan datang dalam bentuk potensi jasa yang dapat diubah, ditukar atau disimpan.

Selanjutnya berdasar beberapa definisi aset di atas dapat disimpulkan bahwa terdapat tiga karakteristik utama yang harus dipenuhi agar suatu objek dapat disebut aset, yaitu:

a) Memiliki manfaat ekonomik yang pasti artinya bahwa untuk dapat disebut sebagai aset, suatu objek harus mengandung manfaat ekonomik di masa datang.

b) Dikuasai atau dikendalikannya aset oleh suatu entitas. Agar

\footnotetext{
21 Agnes Utari Widyaningdyah, 'Perspektif Akuntansj Atas Aset Pengetahuan (Knowledge Asset)' (2009) 1 (1) Jurnal Akuntansi Kontemporer 59, 62.

22 Suryan Widati, 'Kajian Kritis Feminist Posmodernisdalam Formulasi Aset Mental Organisasi Feminis Religius' (2012) 2 (1) Jurnal Reviu Akuntansi dan Keuangan, 173.

23 Suzan Agustri, 'Aplikasi Manajemen Aset Perangkat Produksi Berbasis Web: Studi Kasus PT. Telkomsel' (2013) 4 (2) Jurnal Informatika Global, 1, 2.

24 Doli D. Siregar, Management Aset Strategi Penataan Konsep Pembangunan Berkelanjutan Secara Nasional dalam Konteks Kepala Daerah sebagai CEO's pada Era Globalisasi dan Otonomi Daerah (PT. Gramedia Pustaka Utama 2004) 178.

25 Eddy Mulyadi Soepardi, Memahami Kerugian Keuangan Negara sebagai Salah Satu Unsur Tindak Pidana Korupsi (Fakultas Hukum Pakuan Bogor 2009) 387. Ibid., 386. Ibid.
} 
dapat disebut sebagai aset, suatu objek tidak harus dimiliki oleh entitas tetapi cukup dikuasai oleh entitas. Oleh karena itu, konsep penguasaan atau kendali sangat penting agar aset dapat memiliki manfaat. Penguasaan disini berarti kemampuan entitas untuk mendapatkan, memelihara/ menahan, menukarkan, menggunakan manfaat ekonomik dan mencegah akses pihak lain terhadap manfaat tersebut. Hal ini dilandasi oleh konsep dasar substansi dari aset dan bukan hanya mengejar bentuk yuridis (substance over form) dari aset.

c) Aset timbul sebagai akibat transaksi masa lalu. Kriteria ketiga ini pada dasarnya menyempurnakan kriteria penguasaan dan sekaligus sebagai kriteria atau first-test pengakuan terhadap objek sebagai aset. Aset timbul akibat dari transaksi atau kejadian masa lalu, penguasaan harus didahului oleh transaksi atau kejadian ekonomi.

Dari pengertian serta karakteristik aset yang telah dipaparkan di atas, dapat disimpulkan bahwa yang dimaksud sebagai aset daerah adalah sumber daya ekonomi yang dikuasai dan/atau dimiliki oleh pemerintah daerah sebagai akibat dari peristiwa masa lalu dan dari mana manfaat ekonomi dan/atau sosial di masa depan diharapkan dapat diperoleh, baik oleh pemerintah daerah maupun masyarakat, serta dapat diukur dalam satuan uang. Termasuk sebagai aset daerah ini adalah sumber daya non keuangan yang diperlukan untuk penyediaan jasa bagi masyarakat umum dan sumber-sumber daya yang dipelihara karena alasan sejarah dan budaya.

\section{Keabsahan Ruislag BMD dengan Tanah Milik Yayasan}

Bagian ini akan menjelaskan dua poin pokok yang harus diperhatikan baik oleh Pemerintah maupun Yayasan yang hendak melakukan ruislag. Dua poin pokok yang turut menentukan keabsahan ruislag yang hendak dielaborasi dalam tulisan ini terdiri dari aspek organisasi Yayasan dan kelengkapan dokumen tanah milik Yayasan.

1) Organisasi Yayasan

Subyek hukum dalam perbuatan hukum memegang peranan penting dalam menentukan keabsahan suatu perbuatan hukum. Subyek hukum di kalangan hukum ada yang menggunakan istilah purusa hukum (Oentari Sadino), awak hukum (St.K. Malikul Adil), pribadi hukum (Soerjono Soekamto, Purnadi Purbacaraka) dan sebagainya. ${ }^{28}$ Subyek hukum atau purusa hukum menurut Apeldoorn adalah segala sesuatu yang mempunyai kewenangan hukum atau persoonlijkheid. Kewenangan hukum tersebut merupakan kecakapan untuk menjadi pendukung subyek hukum yang diberikan oleh hukum obyektif.

Dengan demikian, subyek hukum merupakan setiap orang atau badan hukum yang mempunyai hak dan kewajiban, yang menimbulkan wewenang hukum (rechtsbevoegheid). Wewenang subyek hukum terbagi menjadi dua yaitu: pertama, wewenang untuk mempunyai hak (rechtsbevoegdheid), dan kedua, wewenang untuk melakukan (men- 
jalankan) perbuatan hukum dan faktor-faktor yang mempengaruhinya.

Melihat kepada posisi Pemohon dalam ruislag, maka Pemohon merupakan subyek hukum yang memiliki kewenangan untuk melakukan ruislag dengan aset Yayasan. Pada bagian sebelumnya telah dijelaskan bahwa organisasi Yayasan terdiri atas Pembina, Pengurus, dan Pengawas. Pertanyaan lebih lanjutnya adalah siapa yang berwenang mewakili Yayasan dalam tindakan ruislag. Praktik menunjukkan bahwa pemahaman terhadap representatif Yayasan dalam melakukan ruislag masih rendah. Oleh sebab itu, perlu adanya penegasan terhadap siapa yang memiliki legal standing sebagai Pemohon Ruislag.

Pengurus Yayasan merupakan pihak yang tepat sebagai Pemohon ruislag. Sebagaimana Pasal 31 ayat (1) dan Pasal 35 ayat (1) UU No. 16 Tahun 2001 jo. UU No. 28 Tahun 2004 menyatakan bahwa Pengurus adalah organ Yayasan yang melaksanakan kepengurusan Yayasan, dengan demikian, Pengurus Yayasan bertanggungjawab penuh atas kepengurusan Yayasan untuk kepentingan dan tujuan Yayasan serta berhak mewakili Yayasan baik di dalam maupun diluar Pengadilan.

Tindakan ruislag merupakan perbuatan yang melibatkan pengelolaan aset Yayasan yang mana hal tersebut menjadi bagian dari tugas manajemen dari Pengurus. Dengan demikian, Pengurus memiliki kewenangan untuk melakukan ruislag. Selain itu, Pengurus juga memiliki fungsi representatif Yayasan yang melekat padanya. Melihat uraian singkat di atas, maka dapat disim- pulkan bahwa Pemohon dalam pengajuan ruislag harus merupakan Pengurus Yayasan.

2) Kelengkapan Dokumen Tanah Milik Yayasan

Objek ruislag yang berupa tanah tidak terlepas dari acuan hukum pertanahan. Berdasarkan Pasal 4 (1) UU No. 5 tahun 1960 mengatur bahwa yang dapat mempunyai hak atas tanah adalah:
a) Perorangan (sendiri)
b) Perorangan (bersama-sama)
c) Badan Hukum

Lebih spesifik Pasal 4 PP No. 38 Tahun 1963 menjelaskan bahwa Yayasan (bersifat Keagamaan) dapat memiliki hak milik atas tanah yang kemudian menjadi bagian dari aset Yayasan.

Terhadap hak milik atas tanah yang dimiliki oleh Yayasan dapat dilakukan peralihan hak. Peralihan hak atas tanah merupakan suatu perbuatan hukum yang bertujuan memindahkan hak dari suatu pihak ke pihak lain. ${ }^{29}$ Beberapa cara Peralihan Hak Atas Tanah ialah dengan jual beli, tukar-menukar, hibah, pemberian menurut adat, pemasukan dalam perusahan/inbreng, wasiat.

Hibah tanah kepada Yayasan merupakan hal yang relatif sering terjadi sehingga penting bagi Pemerintah untuk melakukan evaluasi terlebih dahulu terkait legalitas hibah tanah Yayasan. Sebagaimana secara umumnya, hibah adalah suatu persetujuan dengan nama si penghibah, diwaktu hidupnya dengan cuma-cuma dan dengan tidak dapat ditarik kembali, menyerahkan sesuatu benda guna keperluan si penerima hibah yang menerima penyerahan itu. Apabila seseorang memberikan harta

29 Hak tanah merupakan hak penguasaan atas tanah yang menjadi kriteria atau tolok ukur. Boedi Harsono, UUPA Bagian Pertama Jilid Pertama (Kelompok Belajar ESA 2003) 24. 
miliknya pada orang lain maka berarti si pemberi itu menghibahkan miliknya itu. Maka dari itu, kata hibah sama artinya dengan istilah "pemberian". 30

Adapun tata cara hibah adalah tata cara penghibahan adalah sebagai berikut.

a. Berdasarkan Pasal $1682 \mathrm{KUH}$ Perdata menyebutkan tiada suatu hibah, kecuali yang disebutkan dalam pasal 1687, dapat atas ancaman batal, dilakukannya selainnya dengan suatu akta notaris, yang aslinya disimpan oleh notaris itu.

b. Berdasarkan Pasal $1683 \mathrm{KUH}$ Perdata menyebutkan tiada suatu hibah mengikat si penghibah, atau menerbitkan suatu akibat yang bagaimanapun, selain mulai hari penghibahan itu dengan kata-kata yang tegas telah diterima oleh si penerima hibah itu sendiri atau oleh seorang yang dengan sesuatu akta otentik oleh si penerima hibah itu telah dikuasakan untuk menerima penghibahan-penghibahan yang telah kepada si penerima hibah atau akan diberikan kepadanya kemudian hari.

c. Berdasarkan Pasal $1685 \mathrm{KUH}$ Perdata menyebutkan penghibahan kepada orang-orang belum dewasa berada di bawah kekuasaan orang tua harus diterima oleh orang yang melakukan kekuasaan orang tua. Penghibahan kepada orang-orang belum dewasa yang berada dibawah perwalian atau orangorang terampu, harus diterima oleh si wali atau si pengampu, yang untuk itu harus dikua- sakan oleh Pengadilan Negeri.

d. Berdasarkan Pasal $1686 \mathrm{KUH}$ Perdata menyebutkan hak milik atas benda-benda yang termaktub dalam penghibahan, sekalipun penghibahan itu telah diterima secara sah, tidaklah berpindah kepada si penerima hibah, selain dengan jalan penyerahan yang dilakukan menurut pasal-pasal 612, 1613, 616, dan selanjutnya.

e. Berdasarkan Pasal $1687 \mathrm{KUH}$ Perdata menyebutkan pemberian -pemberian benda-benda bergerak yang bertubuh atau suratsurat penagihan utang kepada si penunjuk dari tangan satu ke tangan yang lain, tidak memerlukan suatu akta, dan adalah sah dengan penyerahan belaka kepada si penerima hibah atau kepada seorang pihak ketiga yang menerima pemberian itu atas nama si penerima hibah

Selanjutnya agar menjadi alat bukti yang sah, akta hibah harus dibuat dan ditandatangani oleh pejabat yang berwenang serta para pihak yang terkait di dalamnya. Selain itu, dalam pembuatan akta hibah, perlu diperhatikan objek yang akan dihibahkan, karena dalam PP Nomor 24 Tahun 1997 ditentukan bahwa untuk objek hibah tanah harus dibuat akta hibah oleh Pejabat Pembuat Akta Tanah (PPAT).

Sebelum lahirnya PP No. 24 Tahun 1997 tentang Pendaftaran Tanah, bagi mereka yang tunduk kepada KUH Perdata, akta hibah harus dibuat dalam bentuk tertulis dari Notaris. Namun, setelah lahirnya PP No. 24 Tahun 1997, setiap pemberian 
hibah tanah dan bangunan harus dilakukan dengan akta Pejabat Pembuat Akta Tanah (PPAT).

Hal ini sesuai dengan ketentuan Pasal 37 ayat (1) PP No. 24 Tahun 1997: Peralihan hak atas tanah dan hak milik atas satuan rumah susun melalui jual beli, tukar-menukar, hibah, pemasukan dalam perusahaan dan perbuatan hukum pemindahan hak lainnya, kecuali pemindahan hak melalui lelang hanya dapat didaftarkan jika dibuktikan dengan akta yang dibuat oleh PPAT yang berwenang menurut ketentuan peraturan perundang-undangan yang berlaku.

Selain itu keabsahan ruislag dengan tanah Yayasan juga harus memperhatikan keadaan hukum dari tanah tersebut. Manakala terdapat keadaan tanah masih belum dibagi, maka perlu dilakukan tindakan pembagian atau pemecahan sertifikat terlebih dahulu sebelum dilakukannya ruislag demi kepastian hukum. Hal tersebut sesuai dengan PP No. 24 Tahun 1997 tentang Pendaftaran Tanah dan Peraturan Kepala BPN No. 1 Tahun 2010 tentang Standar Pelayanan dan Pengaturan Pertanahan. Hal demikian tentunya akan mengurangi potensi masalah terkait status tanah yang dikuasai oleh Negara paska ruislag sebagaimana diketahui bahwa Undang-Undang (UU) Nomor 1 Tahun 2004 tentang Perbendaharaan Negara Pasal 49 ayat (1) dan (2) juga menghendaki agar tanah yang dikuasai pemerintah pusat/daerah harus disertipikatkan dan bangunan milik negara harus dilengkapi dengan bukti kepemilikan serta ditatausahakan dengan tertib.

\section{PENUTUP}

Keseluruhan pembahasan tulisan ini menyimpulkan bahwa dalam melakukan ruislag atau tukarmenukar BMD dengan tanah milik Yayasan, terdapat dua hal yang perlu diperhatikan untuk menciptakan keabsahan ruislag tersebut yakni pertama, dari aspek organisasi. Baik Pemerintah Daerah maupun Yayasan perlu mencermati legal standing Pemohon dalam pengajuan ruislag adalah Pengurus. Kedua, aspek kelengkapan dokumen tanah milik Yayasan. Dalam hal ini, Yayasan perlu memastikan bahwa tanah milik Yayasan yang hendak ditukarkan harus kepastian hukumnya dengan disertai dengan sertifikat dan melibatkan PPAT.

\section{DAFTAR BACAAN}

\section{Buku}

Sutedi A, Peralihan Hak atas Tanah dan Pendaftarannya (Sinar Grafika 2006).

Sidharta A, Bernard, Refleksi tentang Struktur Ilmu Hukum (Mandar 2000).

Apeldoorn L J, van, Pengantar Ilmu Hukum (Pradnya Paramita 1983).

Ali C, Badan Hukum (Alumni 2005).

Harsono B, UUPA Bagian Pertama Jilid Pertama (Kelompok Belajar ESA 2003).

Siregar D D, Management Aset Strategi Penataan Konsep Pembangunan Berkelanjutan Secara Nasional dalam Konteks Kepala Daerah sebagai CEO's pada Era Globalisasi dan Otonomi Daerah 
(PT. Gramedia Pustaka Utama 2004).

Soepardi E M, Memahami Kerugian Keuangan Negara sebagai Salah Satu Unsur Tindak Pidana Korupsi (Fakultas Hukum Pakuan Bogor 2009).

Panggabean H P, Praktek Peradilan Menangani Kasus Aset Yayasan dan Upaya Penanganan Sengketa melalui Alternatif Penyelesaian Sengketa (Pustaka Sinar Harapan 2002).

Pasaribu K, Masalah-Masalah Hak atas Tanah (Balai Pustaka 2004).

Sastrawidjaja M S, Bunga Rampai Hukum Dagang (PT. Alumni 2005).

Tutik T T, Hukum Perdata dalam Sistem Hukum Indonesia (Prenada Media Group 2008).

Anggara S, Ekologi Administrasi: Holistik, Kontemporer dan Kontekstual (Pustaka Setia 2018).

Subekti, Pokok-Pokok Hukum Perdata (Pembimbing Masa 1996).

Sudikno, Mengenal Hukum (Suatu Pengantar) (Liberty, 1988).

\section{Jurnal}

Agustri S, 'Aplikasi Manajemen Aset Perangkat Produksi Berbasis Web: Studi Kasus PT. Telkomsel' (2013) 4 (2) Jurnal Informatika Global.

Febriana E N, Jayus, Indrayati R, 'Pengelolaan Barang Milik Daerah berdasarkan Peraturan Pemerintah Nomor 27 Tahun 2014 tentang Pengelolaan Barang Milik Negara/Daerah' (2017) 4 (2) Jurnal Lentera Hukum.

Koloay R N D, 'Dampak Positif dan Negatif dalam Tukar Guling Barang Milik Daerah' (2016) 3 (9) Jurnal Ilmu Hukum.
Nindyo $\mathrm{P}$, Tanggung Jawab dan Kewajiban Pengurus PT (Bank) Menurut UU No. 40 Tahun 2007 tentang Perseroan Terbatas' (2007) 5 (3) Buletin Hukum Perbankan dan Kebanksentralan.

Prananingrum D H, 'Telaah terhadap Esensi Subyek Hukum: Manusia dan Badan Hukum' (2014) 8 (1) Jurnal Refleksi Hukum.

Rauta U, Kurnia T S, dan Siswanto A, Telaah Teoretis dan Yuridis Tukar Menukar Barang Milik Daerah dengan Swasta' (2017) 24 (2) Jurnal Hukum Ius Quia Iustum.

Widati S, 'Kajian Kritis Feminist Posmodernisdalam Formulasi Aset Mental Organisasi Feminis Religius' (2012) 2 (1) Jurnal Reviu Akuntansi dan Keuangan.

Widyaningdyah A U, 'Perspektif Akuntansj Atas Aset Pengetahuan (Knowledge Asset)' (2009) 1 (1) Jurnal Akuntansi Kontemporer.

\section{Peraturan Perundang-Undangan}

Undang-Undang Republik Indonesia Nomor 16 Tahun 2001 tentang Yayasan sebagaimana telah diubah terakhir dengan UndangUndang Republik Indonesia Nomor No. 28 Tahun 2004 tentang Perubahan atas UndangUndang Republik Indonesia Nomor 16 Tahun 2001 tentang Yayasan.

Undang-Undang Republik Indonesia Nomor 23 Tahun 2014 tentang Pemerintahan Daerah sebagaimana telah diubah beberapa kali terakhir dengan Undang-Undang Nomor 9 Tahun 2015 tentang Perubahan Kedua atas Undang-Undang Republik 
Indonesia Nomor 23 Tahun 2014 tentang Pemerintahan Daerah.

Peraturan Pemerintah Republik Indonesia Nomor 27 Tahun 2014 tentang Pengelolaan Barang Milik Negara/Daerah.

Peraturan Menteri Dalam Negeri Republik Indonesia Nomor 19 Tahun 2016 tentang Pedoman Pengelolaan Barang Milik Daerah. 
